\title{
Effect of Fiber on Residual Strength and High Temperature Burst Performance of Ultra High Performance Concrete
}

\author{
Huijie Shang, Qianqian Peng \\ College of Civil Engineering and Architecture, Shangqiu University, Shangqiu, Henan, China
}

\begin{abstract}
:
In this paper, the effects of fiber on the residual strength and high temperature burst performance of ultra-high performance concrete are studied. This paper analyzes the performance change law of concrete after high temperature from three aspects: mass loss, ultrasonic wave velocity and compressive strength. The results show that with the increase of heating temperature, the mass loss increases and the ultrasonic wave velocity decreases. The compressive strength of concrete increases gradually before $300{ }^{\circ} \mathrm{C}$ and decreases gradually after $400{ }^{\circ} \mathrm{C}$. Mixing PVA fiber and steel fiber can not only improve the burst resistance of ultra-high performance concrete at high temperature, but also have high residual strength. This paper discusses the high temperature burst mechanism of ultra-high performance concrete, which is caused by the change of steam pressure and microstructure.
\end{abstract}

Keywords: Fiber, Ultra High Performance Concrete, Residual Strength, High Temperature Burst Performance.

\section{INTRODUCTION}

With the improvement of science and technology, modern buildings are increasingly developing to high-rise and underground space, and the safety of buildings is very important. High strength and high performance concrete has been widely used gradually [1-2]. In recent years, ultra-high performance concrete has attracted great attention in the field of civil engineering. As a new concrete, it has developed rapidly in the fields of bridges, roads and so on. Scholars have done a lot of research on the mechanical properties of high-performance concrete at high temperature, the bursting mechanism at high temperature and the preventive measures against bursting [3].

In this paper, the properties of UHPC at high temperature are studied from the aspects of fiber type, mixing mode and aggregate [4-5]. The high temperature treatment test was carried 
Article History: Received: 28 October 2021 Revised: 05 December 2021 Accepted: 10 January 2022 Publication: 28 February 2022

out in a high temperature resistance furnace. The changes of mechanical properties and internal structure of UHPC under different high temperatures were studied by mass loss, ultrasonic wave velocity and compressive strength [6-8]. Combined with XRD diffraction method, the burst mechanism of UHPC under high temperature is discussed, so as to put forward new methods for the study of high temperature resistance of UHPC and new preventive measures for high temperature burst [9-10].

\section{TEST MATERIALS AND METHODS}

\section{Raw material}

Nanjing XIAOYETIAN cement plant P - II 52.5 Portland cement; Silica fume with specific surface area of $22000 \mathrm{~m}^{2} / \mathrm{kg}$ and density of $2.24 \mathrm{~g} / \mathrm{cm}^{3}$; Finely ground slag powder with specific surface area of $1000 \mathrm{~m}^{2} / \mathrm{kg}$ and density of $2.80 \mathrm{~g} / \mathrm{cm} 3$; Grace company adval 180 polycarboxylic acid superplasticizer, water reduction rate $\geq 40 \%$, mass fraction $42 \%$, $\mathrm{pH} 7.1$, density $1.09 \mathrm{~g} / \mathrm{cm}^{3}$, chlorine content less than $0.02 \%$, alkali content less than $0.02 \%$; The fine aggregate is ordinary yellow sand with a maximum particle size of $2.5 \mathrm{~mm}$; The coarse aggregate is basalt gravel with a maximum particle size of $16 \mathrm{~mm}$; The properties of steel fiber and PVA fiber are shown in Table 1, and the chemical composition of silica fume and slag powder is shown in Table 2.

TABLE I. Properties of test fibers

\begin{tabular}{|c|c|c|c|c|c|}
\hline $\begin{array}{c}\text { FIBER } \\
\text { VARIETY }\end{array}$ & $\begin{array}{c}\text { FIBER } \\
\text { LENGTH / } \\
\text { MM }\end{array}$ & COLOUR & $\begin{array}{c}\text { FIBER } \\
\text { DIAMETER / } \\
\text { MM }\end{array}$ & $\begin{array}{c}\text { TENSILE } \\
\text { STRENGTH / } \\
\text { MPA }\end{array}$ & $\begin{array}{c}\text { MODULUS OF } \\
\text { ELASTICITY / } \\
\text { GPA }\end{array}$ \\
\hline PVA FIBER & 12 & White & 0.039 & 1600 & 43 \\
\hline $\begin{array}{c}\text { STEEL } \\
\text { FIBER }\end{array}$ & 13 & Yellow & 0.2 & $>1800$ & 210 \\
\hline
\end{tabular}

TABLE II. Chemical composition of silica fume and slag powder

\begin{tabular}{|c|c|c|c|c|c|c|}
\hline $\begin{array}{c}\text { MIXED WOOD } \\
\text { VARIETY }\end{array}$ & $\mathbf{S i O}_{\mathbf{2}}$ & $\mathbf{A l}_{\mathbf{2}} \mathbf{O}_{\mathbf{3}}$ & $\mathbf{F e}_{\mathbf{2}} \mathbf{O}_{\mathbf{3}}$ & $\mathbf{C a O}$ & $\mathbf{M g O}$ & OTHER \\
\hline SILICA FUME & 93.9 & 0.16 & 0.14 & 0.88 & 0.36 & 1.55 \\
\hline SLAG POWDER & 33.14 & 12.91 & 2.8 & 40 & 6.75 & 4.4 \\
\hline
\end{tabular}

2.Test mix proportion

The coordination of high temperature test is shown in Table 3.

TABLE III. Mix proportion of ultra high performance concrete 


\begin{tabular}{|c|c|c|c|c|c|c|c|c|c|c|}
\hline \multirow{2}{*}{$\begin{array}{c}\text { MIX } \\
\text { PROPOR } \\
\text { TION NO }\end{array}$} & \multicolumn{3}{|c|}{$\begin{array}{c}\text { CEMENTITIOU } \\
\text { S MATERIAL } \\
/ \%\end{array}$} & \multirow{2}{*}{$\begin{array}{c}\text { MASS } \\
\text { RATI } \\
\text { O OF } \\
\text { WAT } \\
\text { ER } \\
\text { TO } \\
\text { RUBB } \\
\text { ER }\end{array}$} & \multirow{2}{*}{$\begin{array}{c}\text { MASS } \\
\text { RATI } \\
\text { O OF } \\
\text { SAND } \\
\text { TO } \\
\text { RUBB } \\
\text { ER }\end{array}$} & \multirow{2}{*}{$\begin{array}{c}\text { MASS } \\
\text { RATI } \\
\text { O OF } \\
\text { STON } \\
\text { E TO } \\
\text { RUBB } \\
\text { ER }\end{array}$} & \multirow{2}{*}{$\begin{array}{c}\text { MASS } \\
\text { RATIO } \\
\text { OF } \\
\text { WATE } \\
\text { R } \\
\text { REDUC } \\
\text { ING } \\
\text { AGENT } \\
\text { TO } \\
\text { RUBBE } \\
\text { R } \\
\text { MATE } \\
\text { RIAL }\end{array}$} & \multicolumn{2}{|c|}{$\begin{array}{c}\text { FIBER } \\
\text { VOLU } \\
\text { ME } \\
\text { RATIO } \\
1 \%\end{array}$} & \multirow{2}{*}{$\begin{array}{c}28 \text { D } \\
\text { COMPRE } \\
\text { SSIVE } \\
\text { STRENGT } \\
\text { H / MPA }\end{array}$} \\
\hline & $\begin{array}{c}\text { Cem } \\
\text { ent }\end{array}$ & $\begin{array}{l}\text { Sili } \\
\text { ca } \\
\text { fu } \\
\text { me }\end{array}$ & $\begin{array}{l}\text { Slag } \\
\text { pow } \\
\text { der }\end{array}$ & & & & & $\begin{array}{c}\text { PV } \\
\text { A } \\
\text { fib } \\
\text { er }\end{array}$ & $\begin{array}{c}\text { Ste } \\
\text { el } \\
\text { fib } \\
\text { er }\end{array}$ & \\
\hline $\mathrm{H} 2$ & 50 & 20 & 30 & 0.19 & 1.2 & 0 & 0.02 & 0 & 0 & 127.1 \\
\hline $\mathrm{H} 2 \mathrm{~L} 1$ & 50 & 20 & 30 & 0.19 & 1.2 & 0 & 0.02 & 0 & 1 & 131.4 \\
\hline H2L3 & 50 & 20 & 30 & 0.19 & 1.2 & 0 & 0.02 & 0 & 3 & 172.5 \\
\hline $\mathrm{H} 2 \mathrm{P} 1$ & 50 & 20 & 30 & 0.19 & 1.2 & 0 & 0.02 & 1 & 0 & 118.1 \\
\hline H2L2P1 & 50 & 20 & 30 & 0.19 & 1.2 & 0 & 0.02 & 1 & 2 & 155.5 \\
\hline $\mathrm{H} 2 \mathrm{G}$ & 50 & 20 & 30 & 0.2 & 1.2 & 1.2 & 0.02 & 0 & 0 & 124.1 \\
\hline H2GL1 & 50 & 20 & 30 & 0.2 & 1.2 & 1.2 & 0.02 & 0 & 1 & 149.4 \\
\hline H2GP1 & 50 & 20 & 30 & 0.2 & 1.2 & 1.2 & 0.02 & 1 & 0 & 123.2 \\
\hline H2GL1P1 & 50 & 20 & 30 & 0.2 & 1.2 & 1.2 & 0.02 & 1 & 1 & 138.3 \\
\hline
\end{tabular}

3.High temperature test equipment

HTF1800-i high temperature resistance furnace produced by Nanjing Haote furnace industry is used for high temperature test, and the furnace size is $400 \mathrm{~mm} \times 200 \mathrm{~mm} \times 200 \mathrm{~mm}$, the heating rate and cooling rate are $5{ }^{\circ} \mathrm{C} / \mathrm{min}$.

\section{Test method}

First dry mix the raw materials (ultra-fine industrial waste residue, cement, yellow sand and stone), and then slowly pour the evenly mixed water and admixture into the mixer during the mixing process, and wet mix for $2 \sim 3$ minutes. When the mixture enters the viscous flow state, evenly sprinkle the fiber and continue stirring for $2 \sim 3 \mathrm{~min}$. At $70.7 \mathrm{~mm} \times 70.7 \mathrm{~mm} \times$ Cast in a $70.7 \mathrm{~mm}$ mold and vibrate for $30 \mathrm{~s}$ to improve compactness. Remove the mold after standard curing for $1 \mathrm{~d}$. The test piece shall be cured in a standard curing box with a temperature of ( $20 \pm$ 2) ${ }^{\circ} \mathrm{C}$ and a relative humidity of $>90 \%$ for 28 days. After curing, the test piece shall be taken out, the surface water trace shall be wiped dry, and it shall stand at room temperature for 3 days. It shall be moved into a high-temperature resistance furnace for high-temperature treatment. The set maximum temperatures are $200,300,400,600,800,900$ and $1000{ }^{\circ} \mathrm{C}$ respectively, and 
Article History: Received: 28 October 2021 Revised: 05 December 2021 Accepted: 10 January 2022 Publication: 28 February 2022

the holding time at the maximum temperature is $4 \mathrm{H}$. After the high temperature treatment, test the relevant performance.

\section{TEST RESULTS AND ANALYSIS}

1.Appearance change of UHPC after high temperature

UHPC specimens were subjected to high-temperature treatment. During the hightemperature treatment, the internal water evaporation of the specimens was less and basically unchanged within $200{ }^{\circ} \mathrm{C}$; At $400{ }^{\circ} \mathrm{C}$, a large amount of water inside the test piece evaporates, white water mist begins to appear at the furnace mouth, and a slight burst sound can be heard at the same time; When the temperature exceeds $400{ }^{\circ} \mathrm{C}$, with the increase of temperature, water droplets and a large amount of water mist appear at the furnace mouth; After $500{ }^{\circ} \mathrm{C}$, the water mist at the furnace mouth basically disappears. UHPC materials mixed with mineral admixtures such as silica fume are more prone to burst due to their dense structure. The specimens without any fiber or with only steel fiber are prone to burst when reaching $400{ }^{\circ} \mathrm{C}$. For the specimens containing PVA fiber, the specimens do not burst during the whole process of heating up, and even only a few specimens show local peeling and surface cracks when heating up to $1000{ }^{\circ} \mathrm{C}$

With the change of temperature, the color of the specimen surface also changes obviously. The ultra-high performance concrete prepared in this paper is gray at room temperature, and the color of the specimen has no obvious change within $300^{\circ} \mathrm{C}$; At $400{ }^{\circ} \mathrm{C}$, the specimen is brown, and microcracks appear on the surface of the specimen without PVA fiber; When PVA fiber was added at $600{ }^{\circ} \mathrm{C}$, the surface of the specimen was gray white with many small cracks; At $800{ }^{\circ} \mathrm{C}$, the surface of the specimen shows light red and the crack width increases obviously; At $900{ }^{\circ} \mathrm{C}$, the surface of the specimen is white, cracks increase, and the surface layer has become powder, which is easy to crush; At $1000{ }^{\circ} \mathrm{C}$, the surface of the test piece is obviously yellow, and there are local black spots on the surface of the test piece containing steel fiber, which is very easy to crush and has low strength.

2.Strength change of ultra high performance concrete after high temperature

The compressive strength of concrete is an important performance index, which is often used as the main parameter of structural design. During the experiment, the specimen without PVA fiber burst at $400{ }^{\circ} \mathrm{C}$, resulting in the loss of strength, while the specimen with PVA fiber did not burst. The change of compressive strength during high temperature is significant. It can be seen from the figure that the strength does not change significantly within $200{ }^{\circ} \mathrm{C}$, but increases significantly at $200 \sim 300{ }^{\circ} \mathrm{C}$. Due to the addition of silica fume and slag ultrafine mixture and the use of superplasticizer, the hydration reaction is strengthened and its strength is improved with the increase of temperature. At the same time, the addition of aggregate and steel fiber will also improve the compressive strength of the material. The steel fiber reinforced UHPC with a volume ratio of $3 \%$ has a large burst degree at $400{ }^{\circ} \mathrm{C}$, so the compressive 
Article History: Received: 28 October 2021 Revised: 05 December 2021 Accepted: 10 January 2022 Publication: 28 February 2022

strength is very small. At $400{ }^{\circ} \mathrm{C}$, the intact test pieces are h211, $\mathrm{H} 2 \mathrm{G}$ and those containing PVA fiber. After $400{ }^{\circ} \mathrm{C}$, the compressive strength decreases gradually with the increase of temperature. At $900{ }^{\circ} \mathrm{C}$, the strength of ultra-high performance concrete decreases by $32.7 \%$ (h2gl1p1) at least and $78.9 \%(\mathrm{~h} 212 \mathrm{p} 1)$ at most. According to the literature, at $400{ }^{\circ} \mathrm{C}$, the strength loss of $\mathrm{C} 40$ concrete is $31.1 \%$ of that at room temperature, while the strength loss of C60 and C70 concrete is $40 \%$ and $37.8 \%$ of that at room temperature. The test piece h2p1 doped with PVA fiber still has a strength of $26.3 \mathrm{MPa}$ at a high temperature of $1000{ }^{\circ} \mathrm{C}$. In the figure, the strength of $\mathrm{h} 2 \mathrm{gp} 1$ and $\mathrm{h} 2 \mathrm{gl} 1 \mathrm{p} 1$ specimens containing aggregate does not change significantly at $600 \sim 800{ }^{\circ} \mathrm{C}$, and a "platform" appears.

3.Variation of ultrasonic wave velocity of ultra high performance concrete after high temperature

The damage degree of concrete after high temperature is reflected by the different propagation speed of ultrasonic in concrete. The denser the concrete structure, the higher the propagation speed. Under the action of high temperature, the concrete gradually loosens and cracks from the surface to the inside, which destroys the integrity of the concrete, resulting in the decline of the propagation speed of ultrasonic wave in the concrete. Therefore, the damage degree of concrete after high temperature can be analyzed and evaluated by the change of ultrasonic wave velocity. Before $400{ }^{\circ} \mathrm{C}$, the decrease of wave velocity is not obvious, indicating that the internal damage of the test piece is small. Only when $\mathrm{h} 211$ is at $400{ }^{\circ} \mathrm{C}$, the wave velocity is $3.2 \mathrm{~km} / \mathrm{s}$, and the internal damage of the test piece is moderate. The wave velocity of the specimen containing PVA fiber changes dramatically between $400{ }^{\circ} \mathrm{C}$ and $800{ }^{\circ} \mathrm{C}$, and is in the trend of greatly decreasing. The minimum attenuation of wave velocity at $400{ }^{\circ} \mathrm{C}$ is $4 \%$ (h2p 1 ), and the maximum attenuation at $800{ }^{\circ} \mathrm{C}$ is $96 \%(\mathrm{~h} 2 \mathrm{~g} 11 \mathrm{p} 1)$, which indicates that the internal structure of the specimen has changed greatly under the action of high temperature, the degree of thermal expansion increases, cracks increase, the degree of damage is large, and the distance of ultrasonic propagation increases. After $800{ }^{\circ} \mathrm{C}$, the decomposition reaction of $\mathrm{Ca}(\mathrm{OH})_{2}$ and $\mathrm{Ca} \mathrm{CO}_{3}$ in the specimen is complete, and the change of wave velocity tends to be stable. For h2p1 and h2l2p1 heated to $1000{ }^{\circ} \mathrm{C}$, at this time, C-S-H decomposes, the internal structure of concrete is damaged more violently, and the wave velocity drops below 1 $\mathrm{km} / \mathrm{s}$.

\section{IV.DISCUSSION ON HIGH TEMPERATURE BURST MECHANISM AND INFLUENCING FACTORS OF ULTRA HIGH PERFORMANCE CONCRETE}

\section{High temperature cracking mechanism of ultra high performance concrete}

There is no unified view on the bursting mechanism of high performance concrete at high temperature. At present, it mainly focuses on steam pressure mechanism and thermal stress mechanism. 
Article History: Received: 28 October 2021 Revised: 05 December 2021 Accepted: 10 January 2022 Publication: 28 February 2022

Cement stone with high strength will be generated during hydration reaction. Silica fume and ground slag will react with cement hydration product $\mathrm{Ca}(\mathrm{OH})_{2}$, which will increase the number of hydration products. At the same time, silica fume and slag can be fully filled in the pores of cement stone, making the internal structure of concrete more dense. Before $400{ }^{\circ} \mathrm{C}$, with the increase of temperature, the capillary water in the concrete gradually evaporates, while the concrete temperature on the outer surface is higher than that on the inside. At the same time, due to the compact structure, the external concrete structure changes, but the interior forms a state of high-temperature steam curing, which increases the degree of internal hydration. This increase in the strength of the internal matrix offsets the strength loss caused by the change of the external structure, and generally makes the material strength in an increasing trend, which well explains the reason for the increase in the strength of ultra-high performance concrete before $400{ }^{\circ} \mathrm{C}$.

At $575^{\circ} \mathrm{C}, \mathrm{Ca}(\mathrm{OH})_{2}$ began to dehydrate, making the internal structure begin to change. At $400 \sim 800 \mathrm{C}$, C S H gel dehydrated and decomposed. With the evaporation of water, the vapor pressure gradually increased, and the pressure gradient in the local area began to appear in the concrete. Because the temperature can not be balanced as a whole, there is a local temperature difference inside, resulting in a thermal stress gradient, which makes a large number of microcracks in the hydration products. At this time, the micro cracks in the concrete are not all connected, but appear in different areas, and there are great differences in steam pressure and thermal stress inside and outside the area. With the increase of temperature, under the dual action of steam pressure and thermal stress, the micro cracks in concrete gradually penetrate and evolve into a large number of macro cracks, which eventually leads to large-area burst failure of concrete specimens. It can be seen that the failure of UHPC is affected by steam pressure and thermal stress.

2.Effect of fiber on high temperature cracking of ultra high performance concrete

When PVA fiber with volume fraction of $1 \%$ is added into the test piece, whether steel fiber or coarse aggregate is added, there is no burst during the heating process, which indicates that the full and uniform addition of PVA fiber can effectively improve the burst resistance of the test piece and reduce the crack propagation of the test piece after high temperature. The melting point of PVA fiber is $210 \sim 230{ }^{\circ} \mathrm{C}$, and PVA fiber melts with the increase of temperature. Where there were fibers, they evolved into tiny pores, which gradually increased, and water vapor also gradually increased. The pores fully dredge the water and steam, and form a state of autoclave curing in the specimen, which promotes the hydration reaction in the concrete and improves the compressive strength of the matrix. Because the temperature rise is from the outside to the inside, the melting of PVA fiber is also from the outside to the inside. Many tiny holes are formed on the concrete surface. With the increase of temperature, there are more and more steam and pores. The existence of pores makes the steam circulate, avoids the formation of internal thermal stress and avoids the occurrence of burst. However, with the increase of 
Article History: Received: 28 October 2021 Revised: 05 December 2021 Accepted: 10 January 2022 Publication: 28 February 2022

temperature, the PVA fiber inside finally melted completely, and finally showed macro local area damage and strength reduction.

\section{CONCLUSION}

(1) the quality and ultrasonic velocity of ultra-high performance concrete decrease with the increase of temperature. The compressive strength of concrete without PVA fiber increases or decreases first and then increases before $300{ }^{\circ} \mathrm{C}$. After $400{ }^{\circ} \mathrm{C}$, the compressive strength of ultra-high performance concrete shows an obvious downward trend.

(2) for the concrete specimen mixed with PVA fiber, there are many micro channels due to the melting of PVA fiber at high temperature, which dredges the steam, so as to improve the burst resistance of UHPC; When steel fiber is mixed alone, the specimen will burst at $400{ }^{\circ} \mathrm{C}$; Mixing PVA and steel fiber can not only improve the burst resistance, but also improve the residual compressive strength after high temperature.

(3) the strength of UHPC specimens after high temperature of $1000{ }^{\circ} \mathrm{C}$ is $26.3 \mathrm{MPa}$ and 36.7 MPa respectively when PVA is mixed alone or mixed with PVA and steel fiber. When two types of fibers are mixed in the concrete containing coarse aggregate, the UHPC specimen still has a strength of $90.2 \mathrm{MPa}$ after high temperature treatment at $900{ }^{\circ} \mathrm{C}$.

(4) the high temperature burst of ultra-high performance concrete is caused by the following two reasons: one is the evaporation of crystalline water, resulting in the increase of internal steam pressure and the formation of internal pressure gradient; Second, the hydration products decompose, the crystal structure changes, resulting in lattice distortion, resulting in burst.

\section{REFERENCES}

1. Liu F S, Zeng Z P, Wu B, et al. Study of the Effect of Cement Asphalt Mortar Disease on Mechanical Properties of CRTS II Slab Ballastless Track. Advanced Materials Research, 2014, 906:305310.

2. Ping W, Xie K Z, Cai D J, et al. The Maximum Gradient of $32 \mathrm{~m}$ Simply-supported Beam Bridge of Ballastless Track Based on the Fastener Force. Journal of Railway Engineering Society, 2015, 32(1).

3. Huang J, Su Q, Liu T, et al. Vibration and Long-Term Performance Analysis of Pile-PlankSupported Low Subgrade of Ballastless Track under Excitation Loads. Shock \& Vibration, 2015, 2015(5):1-12.

4. Wang Q, Wei J, Dong R Z, et al. Fatigue Behavior Analysis of CRTS II Slab Ballastless Track Structure. Journal of Railway Engineering Society, 2014, 31(5):41-47.

5. Wu G, Yang Y, Yang Q, et al. A new type of ballastless track slab reinforced by steel-FRP composite bar and its basic properties. 2014, 47(10):136-144.

6. Zhang, Degan, et al. "An Energy-Balanced Routing Method Based on Forward-Aware Factor for Wireless Sensor Networks." IEEE Transactions on Industrial Informatics, vol. 10, no. 1, pp. 766-773, 2014.

7. Zhang, Degan, et al. "An Energy-Balanced Routing Method Based on Forward-Aware Factor for 
Wireless Sensor Networks." IEEE Transactions on Industrial Informatics, vol. 10, no. 1, pp. 766-773, 2014.

8. Zhang, Xiaoying, et al. "Rotation-based privacy-preserving data aggregation in wireless sensor networks." ICC 2014 - 2014 IEEE International Conference on Communications, pp. 4184-4189, 2014.

9. Jin Zheng, et al. "Auction-based adaptive sensor activation algorithm for target tracking in wireless sensor networks." Future Generation Computer Systems, vol. 39, no. 1, pp.88-99, 2014.

10. Li, Zhe Tao, et al. "A low latency, energy efficient MAC protocol for wireless sensor networks." International Journal of Distributed Sensor Networks, vol. 10, no. 6, pp.1-9, 2015. 